\title{
Cyto-genotoxicity and oxidative stress in common carp (Cyprinus carpio) exposed to a mixture of ibuprofen and diclofenac
}

\author{
Hariz Islas-Flores ${ }^{1} \quad$ | Leobardo Manuel Gómez-Oliván ${ }^{1} \quad$ | Marcela Galar-Martínez ${ }^{2}$ | \\ Esmeralda Michelle Sánchez-Ocampo ${ }^{1}$ | Nely SanJuan-Reyes ${ }^{1}$ | \\ Mariana Ortíz-Reynoso ${ }^{3}$ | Octavio Dublán-García1
}

\begin{abstract}
${ }^{1}$ Laboratorio de Toxicología Ambiental, Facultad de Química, Universidad Autónoma del Estado de México, Paseo Colón intersección Paseo Tollocan s/n. Col. Residencial Colón, Toluca, Estado de México, 50120, México

${ }^{2}$ Laboratorio de Toxicología Acuática, Sección de Graduados e Investigación, Escuela Nacional de Ciencias Biológicas, Instituto Politécnico Nacional, Plan de Ayala y Carpio s/n, México, D.F, 11340, México

${ }^{3}$ Laboratorio de Farmacia, Facultad de Química, Universidad Autónoma del Estado de México, Paseo Colón intersección Paseo Tollocan s/n. Col. Residencial Colón, Toluca, Estado de México, 50120, México

\section{Correspondence}

Leobardo Manuel Gómez-Oliván, Laboratorio de Toxicología Ambiental, Facultad de Química, Universidad Autónoma del Estado de México. Paseo Colón intersección Paseo Tollocan s/n. Col. Residencial Colón, 50120 Toluca, Estado de México, Mexico.

E-mail: Imgomezo@uaemex.mx

Igolivan74@gmail.com
\end{abstract}

Funding information

This study was made possible by support from the Secretaria de Investigación y Estudios Avanzados de la UAEM (Project 3722/2014CID).

\begin{abstract}
Thirty million people worldwide consume each day nonsteroidal anti-inflammatory drugs (NSAIDs), a heterogeneous group of pharmaceuticals used for its analgesic, antipyretic, and antiinflammatory properties. Recent studies report high NSAID concentrations in wastewater treatment plant effluents, in surface, ground, and drinking water, and in sediments. NSAIDs are also known to induce toxicity on aquatic organisms. However, toxicity in natural ecosystems is not usually the result of exposure to a single substance but to a mixture of toxic agents, yet only a few studies have evaluated the toxicity of mixtures. The aim of this study was to evaluate the toxicity induced by diclofenac (DCF), ibuprofen (IBP), and their mixture on a species of commercial interest, the common carp Cyprinus carpio. The median lethal concentration of IBP and DCF was determined, and oxidative stress was evaluated using the following biomarkers: lipid peroxidation and activity of the antioxidant enzymes superoxide dismutase, catalase and glutathione peroxidase. Cyto-genotoxicity was evaluated by micronucleus test, comet assay, and the specific activity of caspase-3. Results show that DCF, IBP, and a mixture of these pharmaceuticals induced free radical production, oxidative stress and cyto-genotoxicity in tissues of $C$. carpio. However, a greater effect was elicited by the mixture than by either pharmaceutical alone in some biomarkers evaluated, particularly in gill.
\end{abstract}

\section{KEYWORDS}

caspase- 3 , comet assay, Cyprinus carpio, micronuclei, nonsteroidal anti-inflammatory drugs, oxidative stress
Abbreviations: CAT, catalase; COX, cyclooxygenase; CYP, cytochrome P450; $\mathrm{DCF}$, diclofenac; GPx, glutathione peroxidase; IBP, ibuprofen; $\mathrm{LC}_{50}$, median lethal concentration; LOAEL, lowest observed adverse effect level; LPX, lipid peroxidation; MDA, malondialdehyde; MEC, molar extinction coefficient; $\mathrm{MNi}$, micronuclei; MS, mass spectrometer; NPX, naproxen; NSAID, nonsteroidal anti-inflammatory drug; PAR, paracetamol; pNA, $p$-nitroanilide; ROS, reactive oxygen species; SOD, superoxide dismutase; TBA, thiobarbituric acid; TCA, trichloroacetic acid; WWTP, wastewater treatment plant.

\section{1 | INTRODUCTION}

In recent years, there has been growing concern about trace concentrations of pharmaceuticals in aquatic environments and their potential effects. $^{1,2}$ Some pharmaceuticals are metabolized after administration while others remain intact when being excreted. Thus, a mixture of these agents and their metabolites enters municipal sewage and wastewater treatment plants. ${ }^{3}$ Depending on their polarity, water solubility, and persistence, some of these compounds are not completely 
removed by treatment processes, and the unaltered pharmaceutical and/or their metabolites may re-enter surface water. These products can also enter the environment as a result of the disposal of unused or expired medications, or through pharmaceutical industry discharges. ${ }^{4}$ Once in the environment, these compounds are considered emerging contaminants. Richardson et al. ${ }^{5}$ define these as unregulated compounds that can pose a risk to aquatic ecosystems.

These pollutants include nonsteroidal anti-inflammatory drugs (NSAIDs), which is one of the most commonly used groups of pharmaceuticals. Takagi et al. ${ }^{6}$ report that this group accounts for more than 70 million prescriptions annually in Britain, Spain, and Japan. They are also the sixth best-selling group of medications in the world, with an annual production of several thousand tons. ${ }^{7}$ In Mexico, sales of 201 million dollars (USD) were reported in 2012 and an average annual growth rate of $1.3 \%$ is expected to occur from 2013 to $2017 .{ }^{8}$ NSAIDs have diverse anti-inflammatory, analgesic, and antipyretic properties. They are a heterogeneous group and share diverse therapeutic actions and adverse effects. ${ }^{9}$ Their mechanism of action is through inhibition of the cyclooxygenase (COX) enzymes: COX-1 and COX-2, which convert arachidonic acid to prostaglandins and thromboxanes, mediators involved in diverse homeostatic processes throughout the body. ${ }^{7,9,10}$ The most common members of this group of pharmaceuticals in terms of consumption and biological action are naproxen (NPX), paracetamol (PAR), diclofenac (DCF), ibuprofen (IBP), and acetylsalicylic acid. ${ }^{11}$

Environmentally, the importance of NSAIDs lies in their inherent properties of persistence, bioaccumulative nature, water solubility, low volatility, and low tendency for adsorption by organic matter, which enable them to remain in the aquatic environment for extended periods, ${ }^{12,13}$ favoring their uptake and bioconcentration by hydrobionts. IBP and DCF have been detected in water bodies worldwide at concentrations ranging from $\mu \mathrm{g} \mathrm{L}^{-1}$ to $\mathrm{ng} \mathrm{L}^{-1} \cdot{ }^{14-17}$ In Mexico, several studies have reported their presence in effluents and water systems. Siemens et al. ${ }^{18}$ found IBP and DCF at concentrations of 0.12-2.30 $\mu \mathrm{g}$ $\mathrm{L}^{-1}$ in Mexico City effluent in the Mezquital Valley; Gibson et al. ${ }^{19}$ detected 742-4824 $\mathrm{ng} \mathrm{L}^{-1}$ in wastewater from the Tula Valley; while Felix-Cañedo et al. ${ }^{20}$ recorded $25-100 \mathrm{ng} \mathrm{L}^{-1}$ in surface water and 1-5 ng L $\mathrm{L}^{-1}$ in ground water in tributaries of the Lerma-Cutzamala system, one of the largest water supply networks in Latin America.

Trace concentrations of these compounds have been reported to induce toxicity in diverse aquatic organisms. DCF induces kidney damage and affects reproduction and growth in Daphnia magna and D. longispira. ${ }^{21-23}$ It also induces damage on kidney, gill, and other tissues in Salmo trutta $f$. fario, ${ }^{24}$ while IBP significantly affects the growth of several bacterial and fungal species. ${ }^{25}$ Furthermore, previous studies have reported that NSAIDs such as DCF, IBP, NPX, and PAR induce oxidative stress and genotoxicity in D. magna, Hyalella azteca, and Cyprinus carpio. ${ }^{26-30}$

Controlled production of free radicals and maintenance of redox homeostasis are essential for the physiological health of organisms. The formation of reactive oxygen species (ROS) is induced by internal and external factors such as phagocytes, enzymes-for example, cytochrome P450 (CYP) monooxygenases-radiation, and exogenous chem- ical agents. Similarly, ROS production can be decreased or reversed by several enzymes, called antioxidant enzymes, such as superoxide dismutase (SOD), catalase (CAT), and glutathione peroxidase (GPx) ${ }^{31}$. Endogenous ROS act as a second messenger in signal transduction and are thought to be important in ion transport, host immune defenses, DNA transcription, and cellular apoptosis. ${ }^{32,33}$ However, ROS can also elicit damage by binding covalently or irreversibly to cellular macromolecules. Oxidative stress, an imbalance between ROS production and the antioxidant defense mechanisms of a cell or tissue, elicits the irreversible oxidation of proteins, lipids, and DNA, leading to the inactivation of many enzymes and cell death. It can also affect gene expression by interfering with the activity of redox-sensitive transcription factors as well as signal transduction by oxidation of thiols. ${ }^{34}$

Bioindicators can be used to evaluate the toxic impact of contaminants in water bodies. Toxicity studies in fish are one of the most effective methods for understanding the deleterious effects of environmental contaminants in aquatic systems. Fish play a major role in aquatic food webs where they generally occupy an intermediate or higher position: not only are they fed upon by a variety of aquatic predators, they are also a major food source for humans around the world. ${ }^{35}$ The common carp Cyprinus carpio is frequently used as a bioindicator species ${ }^{36}$ since cyprinids are quantitatively the most important group of teleost fish cultured worldwide for commercial purposes and are also very resistant and easy to maintain.

Toxicity in natural ecosystems is not usually due to exposure to a single substance; it is the result of exposure to a mixture of several toxic agents. Thus, it is necessary to understand the impact and potential toxicity of pollutants in combination, particularly if pollution is considered to be chronic. However, very few studies have examined the effects of mixtures. ${ }^{37-39}$ Therefore, this study aimed to evaluate the toxicity induced by sublethal concentrations of IBP and DCF in isolated form and as a mixture on diverse tissues of $C$. carpio, using oxidative stress and cytogenotoxicity biomarkers in order to assess the potential risk posed by a waterborne mixture of these pharmaceuticals to the physiology and survival of aquatic organisms. We choose DCF and IBP because they are among the most consumed NSAIDs worldwide and it has been reported that these pharmaceuticals have shown greater toxicity for aquatic organisms, plus in regard to Mexico, in 2012, was reported sales of 201 million dollars (mdd) and is expected to have a rate average annual growth of $1.3 \%$ from 2013 to $2017,{ }^{8}$ because of this, is very important to determine if this represents a risk for organisms.

\section{2 | MATERIALS AND METHODS}

\section{1 | Test substances}

IBP $\mathrm{C}_{13} \mathrm{H}_{18} \mathrm{O}_{2}$ (CAS Number 15687-27-1, >98\% purity) and DCF $\mathrm{C}_{14} \mathrm{H}_{11} \mathrm{C}_{12} \mathrm{NO}_{2}$ (CAS number 15307-86-5, $>99 \%$ purity), were purchased from Sigma-Aldrich (Toluca, Mexico; henceforth SIAL/T). Stock solutions were prepared by dissolving $1 \mathrm{~g}$ IBP or DCF in $500 \mathrm{~mL}$ of deionized water. 


\section{2 | Specimen procurement and maintenance}

Three-month-old common carp (C. carpio) juveniles $18.4 \pm 0.31 \mathrm{~cm}$ long and weighing $50.7 \pm 7.8 \mathrm{~g}$ were obtained from the aquaculture facility in Tiacaque (State of Mexico), transported to the laboratory in polyethylene bags containing oxygenated water, stocked in a large tank with dechlorinated tap water (previously reconstituted with salts; see Section 2.3) and acclimated for 30 days prior to the experiment. During acclimation, carp were fed Pedregal Silver ${ }^{\mathrm{TM}}$ fish food and 3/4 of the tank water was replaced every $24 \mathrm{~h}$. The physicochemical characteristics of tap water reconstituted with salts were maintained, that is, temperature $20 \pm 2^{\circ} \mathrm{C}$, oxygen concentration $80 \%-90 \%$, pH 7.5-8.0, total alkalinity $17.8 \pm 7.3 \mathrm{mg} \mathrm{L}^{-1}$, total hardness $18.7 \pm 0.6 \mathrm{mg} \mathrm{L}^{-1}$. A natural light/dark photoperiod (12:12 h) was maintained. During the aquaculture period, fish were not exposed to any pharmaceuticals.

All procedures were performed in accordance with the ethical protocols of care, use, and management of the species used in the testing of the Universidad Autónoma del Estado de México. The specifications mentioned in the corresponding Official Mexican Standards were also considered (NOM-062-ZOO- 1999, Technical specifications for the production, care, and use of laboratory animals).

\section{3 | Median lethal concentration ( $\left.\mathrm{LC}_{50}\right)$}

Test systems $(120 \times 80 \times 40-\mathrm{cm}$ glass tanks) filled with water reconstituted with the following salts: $\mathrm{NaHCO}_{3}$ (174 mg L $\mathrm{L}^{-1}$, SIAL/T), $\mathrm{MgSO}_{4}$ (120 mg L ${ }^{-1}$, Sigma-Aldrich, St. Louis MO; henceforth SIAL/S), $\mathrm{KCl}\left(8 \mathrm{mg} \mathrm{L}^{-1}\right.$, Vetec, SIAL/S), and $\mathrm{CaSO}_{4} \cdot 2 \mathrm{H}_{2} \mathrm{O}\left(120 \mathrm{mg} \mathrm{L}^{-1}, \mathrm{SIAL} / \mathrm{S}\right)$ were maintained at room temperature $\left(20^{\circ} \mathrm{C} \pm 2^{\circ} \mathrm{C}\right)$ with constant aeration and a natural light/dark photoperiod (12:12 h). Static systems without renewal of test solutions were used. Fish were not fed during exposure.

To determine the $\mathrm{LC}_{50}$ of IBP and DCF, seven exposure systems with different nominal concentrations of $\operatorname{IBP}(9.5,18.9,37.7,75.2$, 150.0, 300.8, and $\left.600 \mathrm{mg} \mathrm{L}^{-1}\right)$ and six with $\operatorname{DCF}(9.5,18.9,37.7,75.2$, 300.8 , and $600 \mathrm{mg} \mathrm{L}^{-1}$ ) plus a NSAID-free control system were set up, and 10 randomly selected carp were placed in each. The assay was performed in triplicate, using a total of 420 fish.

Duration of exposure was $96 \mathrm{~h}$, at the end of which the number of dead specimens in each system was counted. The $96-\mathrm{h} \mathrm{LC} \mathrm{L}_{50}$ of IBP and DCF and their corresponding 95\% confidence limits $(P<0.05)$ were estimated by Probit analysis v3.3 (US-EPA, 2013). These data were used to estimate the test concentrations to be used in sublethal toxicity assays. The concentration-response curve in the acute toxicity assay was constructed and the lowest concentration with a statistically significant effect was assumed to be the LOAEL (lowest observed adverse effect level).

\subsection{Sublethal toxicity assays}

NSAIDs were added at a nominal concentration equal to the LOAEL (i. e., $17.6 \mathrm{mg} \mathrm{IBP} \mathrm{L}^{-1}$ and $7.10 \mathrm{mg} \mathrm{DCF} \mathrm{L}^{-1}$ ) in isolated form or as a mixture to five exposure systems with six carp each. A time dependent exposure set up was performed for the following exposure periods: 12 ,
24, 48, 72, and 96 h. An NSAID-free control system was set up for each period. Assays were performed in triplicate, using a total of 360 fish.

At the end of the exposure period, fish were removed from the systems and placed in a tank with $50 \mathrm{mg} \mathrm{L}^{-1}$ of clove oil as an anesthetic $^{40}$. Anesthetized specimens were placed in a lateral position and blood was collected with a heparinized 1-mL hypodermic syringe by puncture of the caudal vessel performed laterally near the base of the caudal peduncle, at mid-height of the anal fin and ventral to the lateral line. Six hundred microliters of blood samples were collected in heparinized tubes, placed in PBS and ultrasonicated, and used for the oxidative stress determinations. Of the remaining blood $200 \mu \mathrm{L}$ were used immediately in the micronucleus test and comet assay, and $100 \mu \mathrm{L}$ were placed in PBS (complete to $1 \mathrm{~mL}$ ) and stored at $-70^{\circ} \mathrm{C}$ prior to analysis of the specific activity of caspase-3.

After puncture, specimens were sacrificed by cervical dislocation and placed in an ice bath. The gill, liver and brain were removed for evaluation of oxidative stress, placed in phosphate buffer solution (PBS) [0.138 M NaCl (SIAL/T); $0.0027 \mathrm{M} \mathrm{KCl]} \mathrm{pH} 7.4$ and separately homogenized. The homogenate was centrifuged at $12,500 \mathrm{rpm}$ and $-4^{\circ} \mathrm{C}$ for $15 \mathrm{~min}$. Tissue samples were stored at $-70^{\circ} \mathrm{C}$ prior to analysis. The following oxidative stress biomarkers were evaluated: lipid peroxidation (LPX) and SOD, CAT, and GPx activity. These bioassays were performed on the supernatant of the tissues or ultrasonicated blood and the assay was performed in triplicate.

\subsection{1 | Determination of oxidative stress}

\subsubsection{1 | Determination of LPX}

LPX was determined by Büege and Aust ${ }^{41}$ method. To $100 \mu \mathrm{L}$ of supernatant (of the tissues) or blood was added Tris- $\mathrm{HCl}$ buffer solution $\mathrm{pH} 7.4$ (SIAL/S) until a $1 \mathrm{~mL}$ volume was attained. Samples were incubated at $37^{\circ} \mathrm{C}$ for $30 \mathrm{~min} ; 2 \mathrm{~mL}$ TBA-TCA reagent [0.375\% thiobarbituric acid (TBA, Fluka, SIAL/T) in 15\% trichloroacetic acid (TCA, SIAL/ S)] was added prior to shaking in a vortex. Samples were then heated to boiling for $45 \mathrm{~min}$, allowed to cool, and the precipitate removed by centrifugation at $3,000 \mathrm{rpm}$ for $10 \mathrm{~min}$. Absorbance was read at $535 \mathrm{~nm}$ against a reaction blank. Malondialdehyde (MDA) content was calculated using the molar extinction coefficient (MEC) of MDA (1.56 $\left.\times 10^{5} \mathrm{M} \mathrm{cm}^{-1}\right)$. Results were expressed as $\mathrm{mM} \mathrm{MDA} \mathrm{mg}{ }^{-1}$ protein.

\subsubsection{Determination of SOD activity}

SOD activity was determined by Misra and Fridovich ${ }^{42}$ method. To 40 $\mu \mathrm{L}$ of supernatant (of the tissues) or blood in a $1-\mathrm{cm}$ cuvette was added $260 \mu \mathrm{L}$ carbonate buffer solution ( $50 \mathrm{mM}$ sodium carbonate, $0.1 \mathrm{mM}$ EDTA) $\mathrm{pH} 10.2$ and $200 \mu \mathrm{L}$ adrenaline $(30 \mathrm{mM})$; all reagents were obtained from SIAL/S. Absorbance was read at $480 \mathrm{~nm}$ after $30 \mathrm{~s}$ and 5 min. Enzyme activity was determined by interpolating the data on a type curve and results were expressed as IU SOD $\mathrm{mg}^{-1}$ protein.

\subsubsection{3 | Determination of CAT activity}

CAT activity was determined by Radi et al. ${ }^{43}$ method. To $20 \mu \mathrm{L}$ of supernatant (of the tissues) or blood was added $1 \mathrm{~mL}$ isolation buffer solution [0.3 M saccharose (Vetec), $1 \mathrm{~mL}$ EDTA, $5 \mathrm{mM}$ HEPES, $5 \mathrm{mM}$ 
$\mathrm{KH}_{2} \mathrm{PO}_{4}$ (Vetec)] and $0.2 \mathrm{~mL}$ of a hydrogen peroxide solution ( $20 \mathrm{mM}$, Vetec); all reagents SIAL/S. Absorbance was read at $240 \mathrm{~nm}$ after 0 and $60 \mathrm{~s}$. The absorbance value obtained for each of these times was substituted in the formula: CAT activity $\left.=\left(A_{0}-A_{60}\right) / M E C\right)$, where the MEC of $\mathrm{H}_{2} \mathrm{O}_{2}$ is $0.043 \mathrm{mM} \mathrm{cm}^{-1}$, and results were expressed as $\mu \mathrm{M}$ $\mathrm{H}_{2} \mathrm{O}_{2}$ min $^{-} \mathrm{mg}^{-1}$ protein.

\subsubsection{Determination of GPx activity}

GPx activity was determined by Gunzler and Flohe-Clairborne ${ }^{44}$ method as modified by Stephensen et al. ${ }^{45}$ To $100 \mu \mathrm{L}$ of supernatant (of the tissues) or blood was added $10 \mu \mathrm{L}$ glutathione reductase (2 $\mathrm{U}$ glutathione reductase, SIAL/S), $290 \mu \mathrm{L}$ reaction buffer $[50 \mathrm{mM}$ $\mathrm{K}_{2} \mathrm{HPO}_{4}$ (Vetec), $50 \mathrm{mM} \mathrm{KH} \mathrm{PO}_{4} \mathrm{pH}$ 7.0, $3.5 \mathrm{mM}$ reduced glutathione (Fluka), $1 \mathrm{mM}$ sodium azide, $0.12 \mathrm{mM}$ NADPH (all SIAL/T)] and $100 \mu \mathrm{L}$ $\mathrm{H}_{2} \mathrm{O}_{2}$. Absorbance was read at $340 \mathrm{~nm}$ after 0 and $60 \mathrm{~s}$. Activity was estimated using the equation: $G P x$ activity $\left.=\left(A_{0}-A_{60}\right) / M E C\right)$, where the MEC of $\mathrm{NADPH}=6.2 \mathrm{mM} \mathrm{cm}^{-1}$. Results were expressed as $\mathrm{mM}$ $\mathrm{NADPH} \mathrm{min}^{-1} \mathrm{mg}^{-1}$ protein.

\subsubsection{Determination of total protein content}

Total protein content was determined by Bradford ${ }^{46}$ method. To $25 \mu \mathrm{L}$ of supernatant (of the tissues) or blood was added $75 \mu \mathrm{L}$ deionized water and $2.5 \mathrm{~mL}$ Bradford's reagent [0.05 g Coommassie Blue dye, $25 \mathrm{~mL}$ of $96 \%$ ethanol, and $50 \mathrm{~mL} \mathrm{H}_{3} \mathrm{PO}_{4}$ (all reagents SIAL/T), in $500 \mathrm{~mL}$ deionized water]. The test tubes were shaken and allowed to rest for $5 \mathrm{~min}$ prior to reading absorbance at $595 \mathrm{~nm}$ and interpolating on a bovine albumin curve (SIAL/T). Total protein content of each sample was determined and used to express the results of oxidative stress biomarkers and the specific activity of caspase- 3 .

\subsubsection{Evaluation of cyto-genotoxicity}

\subsubsection{1 | Micronucleus test}

A smear of blood from each specimen was fixed in pure ethanol for 5 min, then stained with $10 \%$ Giemsa (SIAL/T) for 9 min. A total of 1000 cells from each sample were examined with a light microscope and frequency of micronuclei (MNi) was expressed as the total number of micronucleated cells per 1000 cells. ${ }^{47}$ Criteria used to determine presence of $\mathrm{MNi}$ were non-linkage of small ovoid or round nuclei with main nucleus, color, and staining intensity similar to main nucleus, ${ }^{48}$ and diameter $1 / 5-1 / 20$ of main nucleus. ${ }^{49}$

\subsubsection{2 | Comet assay}

DNA damage was evaluated by comet assay as proposed by Tice et al. ${ }^{50}$ and Lankoff et al. ${ }^{51}$ Fully frosted slides were prepared $1 \mathrm{~h}$ before the sample was obtained. Slides were initially coated with a $200-\mu \mathrm{L}$ layer of $1 \%$ agarose. Then $10 \mu \mathrm{L}$ blood was mixed with $75 \mu \mathrm{L}$ of $0.75 \%$ agarose. To extract DNA, slides were placed in a Coplin jar with lysis solution (2.5 M NaOH, 10 M EDTA, $10 \mathrm{mM}$ Trizma base, $10 \%$ DMSO, $1 \%$ triton $\mathrm{X}-100) \mathrm{pH} 10$, for $1 \mathrm{~h}$ at $4^{\circ} \mathrm{C}$. All reagents and gels were obtained from SIAL/S.

Slides were placed in the electrophoresis chamber for 20 min with an alkaline solution (300 mM NaOH, $1 \mathrm{mM}$ EDTA) pH 13. Electrophoresis was performed at $300 \mu \mathrm{Amp}, 25 \mathrm{~V}$, and $\mathrm{pH}>13$ for $20 \mathrm{~min}$, and was stopped with a neutralization buffer (0.4 M Trizma base, $\mathrm{pH}$ 7.4).
The DNA was stained with $50 \mu \mathrm{L}$ ethidium bromide (SIAL/S) and examined with a Zeiss Axiophot KS400 epifluorescence microscope equipped with a 510-560 nm filter and attached to an image analyzer with a program for measurement of the cell nucleus. A total of 100 measurements per replicate were made and the damage index (percentage of DNA damage in the tail) was obtained.

\subsubsection{Specific activity of caspase-3}

2.4.2.3.1 Cellular extract preparation. Jurkat cells (ATCC \# TIB-152) were grown in RPMI-1640 medium containing $10 \%$ fetal bovine serumin a humidified, $5 \% \mathrm{CO} 2$ incubator at $37^{\circ} \mathrm{C}$, as recommended by ATCC. The cell density was adjusted to 106 cells $\mathrm{mL}^{-1}$, and $50 \mathrm{ng}$ $\mathrm{mL}^{-1}$ of anti-Fas mAb (clone \#CH-11, MBL International, Cat. \# SY001) was added to the Jurkat cells as a positive (induced apoptosis) control. For inhibited apoptosis samples, $125 \mu \mathrm{L}$ Z-VAD-FMK [carbobenzoxy-valyl-alanylaspartyl-(O-methyl)-fluoromethylketone] inhibitor (20 mM) was added to the cells at the same time as the anti-Fas mAb. Samples were incubated overnight for $16 \mathrm{~h}$ at $37^{\circ} \mathrm{C}$ in a humidified, $5 \%$ $\mathrm{CO}_{2}$ atmosphere. Cells were harvested by centrifugation at $450 \times \mathrm{g}$ and $4^{\circ} \mathrm{C}$ for $10 \mathrm{~min}$. The cell pellet was maintained on ice, then washed with ice-cold PBS and resuspended in Cell Lysis Buffer at a concentration of 108 cells $\mathrm{mL}^{-1}$. Cells were lysed by freeze-thaw, then incubated on ice for $15 \mathrm{~min}$. Cell lysates were centrifuged at 15,000 $\times \mathrm{g}$ and $4^{\circ} \mathrm{C}$ for $20 \mathrm{~min}$ and the supernatant fraction was collected.

2.4.2.3.2 Colorimetric assay. A colorimetric assay kit (CaspACE ${ }^{\mathrm{TM}}$, Promega, Madison, WI), the substrate of which binds to the enzyme, releasing $p$-nitroaniline (pNA), and an UltraCruz ${ }^{\mathrm{TM}}$ microplate with flat-bottom wells were used. A reaction blank was prepared using $32 \mu \mathrm{L}$ of caspase buffer [312.5 mM HEPES, pH 7.5; 31.25\% sucrose; $0.3125 \%$ CHAPS (3- [(3-cholamido-propyl)-dimethylammonio]-1-propane-sulfonate)], $2 \mu \mathrm{L}$ DMSO, $10 \mu \mathrm{L}$ dithiothreitol (DTT; $100 \mathrm{mM}$ ), and $54 \mu \mathrm{L}$ deionized water. The following were used: for the control and exposure groups, $32 \mu \mathrm{L}$ caspase buffer, $2 \mu \mathrm{L}$ DMSO, $10 \mu \mathrm{L}$ DTT, $20 \mu \mathrm{L}$ blood, and $54 \mu \mathrm{L}$ deionized water; for the positive control, $32 \mu \mathrm{L}$ caspase buffer, $2 \mu \mathrm{L}$ DMSO, $10 \mu \mathrm{L}$ DTT, $20 \mu \mathrm{L}$ cellular extract, and $34 \mu \mathrm{L}$ deionized water; for inhibited apoptosis samples, $32 \mu \mathrm{L}$ caspase buffer, $2 \mu \mathrm{L}$ DMSO, $10 \mu \mathrm{L}$ DTT, 20 $\mu \mathrm{L}$ cellular extract, and $34 \mu \mathrm{L}$ deionized water. After all solutions had been transferred, $2 \mu \mathrm{L}$ of substrate DEVD-pNA was added to each well. The microplate was covered with parafilm and incubated for $4 \mathrm{~h}$ at $37^{\circ} \mathrm{C}$. Absorbance was read at $405 \mathrm{~nm}$ and the specific activity of caspase- 3 was calculated. Results were expressed as nMfree pNA $\mathrm{h}^{-1} \mu \mathrm{g}$ protein $^{-1}$. Total protein content was determined by the Bradfordmethod. ${ }^{46}$

\subsection{IBP and DCF quantification by liquid chromatography-tandem mass spectrometry (LC-MS/MS)}

Six carp were placed in each of five exposure systems similar to those described in Section 2.3 and a concentration equal to the LOAEL of IBP (17.6 mg L ${ }^{-1}$ ), DCF (7.10 $\mathrm{mg} \mathrm{L}^{-1}$ ), or a mixture of both was added, also the NSAID-free control system used in the determinations were 


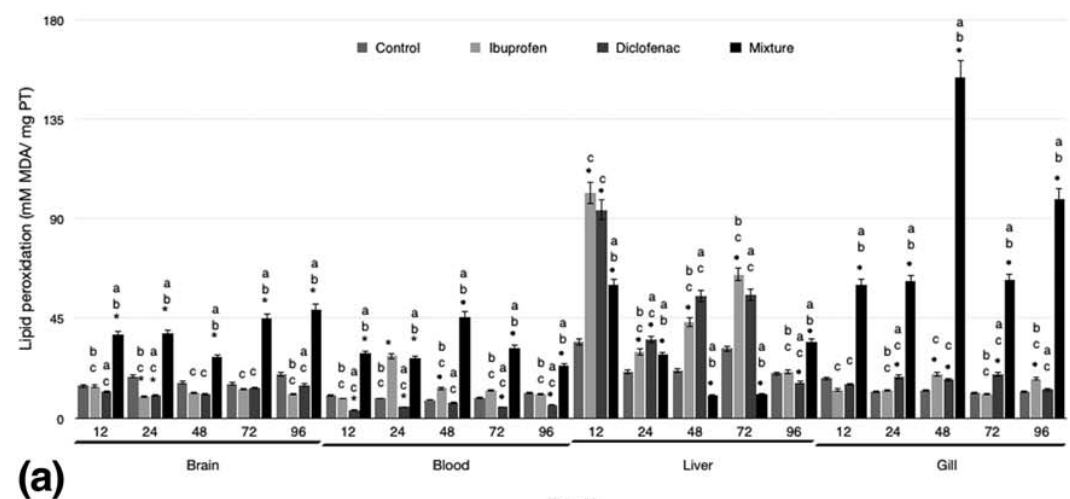

(a)
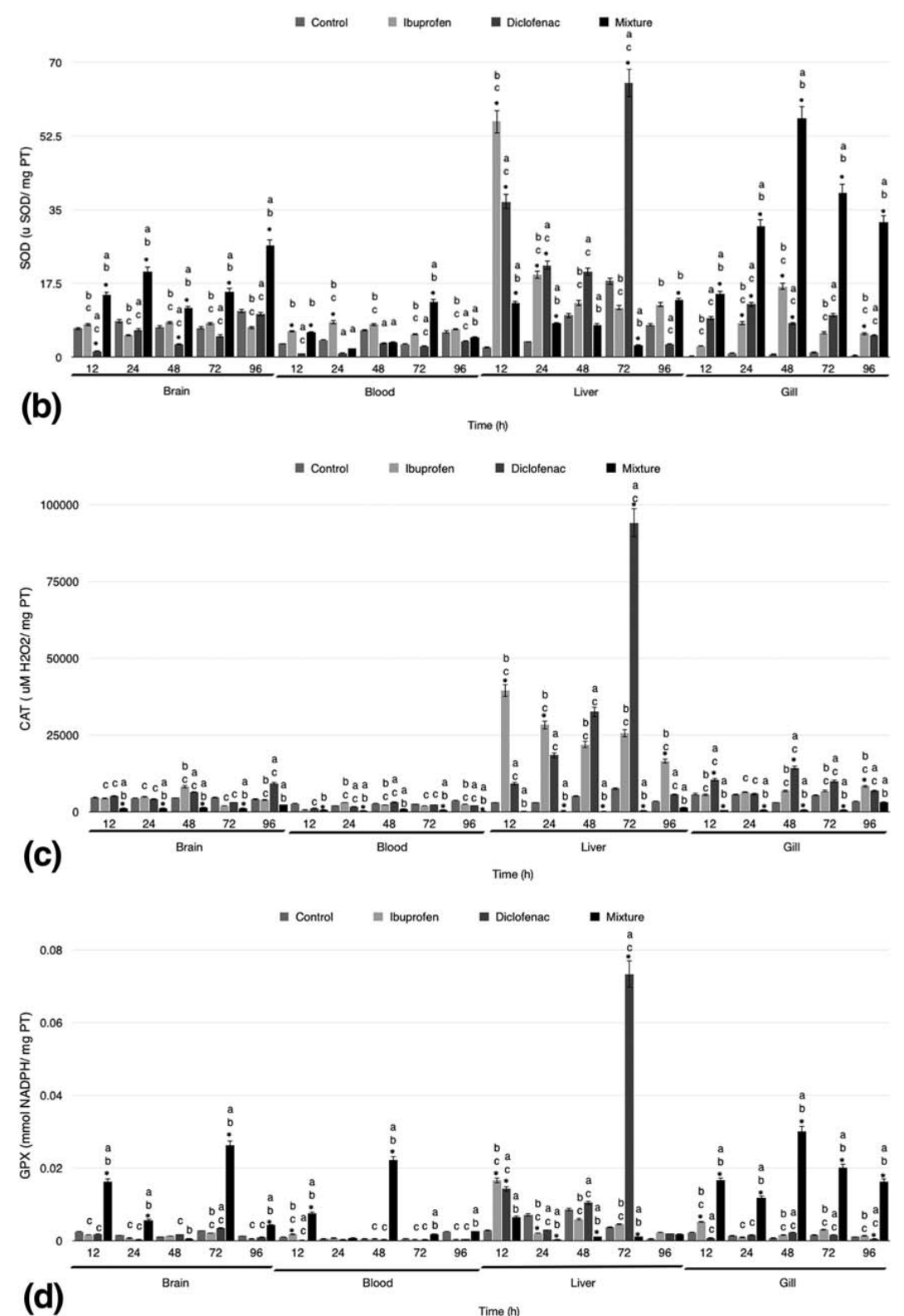

FIGURE 1 Biomarkers of oxidative stress evaluated in in brain, blood, liver, and gill of Cyprinus carpio exposed to ibuprofen and diclofenac in isolated form and as a mixture: (a) Lipid peroxidation, (b) Superoxide dismutase activity, (c) Catalase activity, and (d) Glutathione peroxidase activity. Values are the mean $\pm \mathrm{SE} .{ }^{*}$ Significantly different from control group. Lowercase letters indicate a significant difference relative to specimens exposed to ${ }^{a}$ ibuprofen, ${ }^{b}$ diclofenac, and ${ }^{c}$ the binary mixture $(P<0.05)$, ANOVA and Bonferroni 
TABLE 1 Additive interaction values calculated using ibuprofen and diclofenac in isolated form, and the corresponding actual values determined with each biomarker in different tissues of $C$. carpio after exposure to a mixture of these pharmaceuticals

\begin{tabular}{|c|c|c|c|c|c|c|c|c|c|}
\hline \multirow[b]{3}{*}{ Biomarkers } & \multirow[b]{3}{*}{ Tissue } & \multicolumn{8}{|l|}{ Time (h) } \\
\hline & & \multicolumn{2}{|l|}{$\underline{24}$} & \multicolumn{2}{|l|}{48} & \multicolumn{2}{|l|}{72} & \multicolumn{2}{|l|}{96} \\
\hline & & $\begin{array}{l}\text { Additive } \\
\text { interaction }\end{array}$ & $\begin{array}{l}\text { Actual } \\
\text { value }\end{array}$ & $\begin{array}{l}\text { Additive } \\
\text { interaction }\end{array}$ & $\begin{array}{l}\text { Actual } \\
\text { value }\end{array}$ & $\begin{array}{l}\text { Additive } \\
\text { interaction }\end{array}$ & $\begin{array}{l}\text { Actual } \\
\text { value }\end{array}$ & $\begin{array}{l}\text { Additive } \\
\text { interaction }\end{array}$ & $\begin{array}{l}\text { Actual } \\
\text { value }\end{array}$ \\
\hline \multirow{4}{*}{$\begin{array}{l}\text { LPX (mM MDA/ } \\
\text { mg protein) }\end{array}$} & Brain & 20.057 & $\uparrow 38.039$ & 22.162 & $\uparrow 27.554$ & 26.439 & 45.156 & 25.582 & $\downarrow 10.886$ \\
\hline & Blood & 33.146 & 27.070 & 20.178 & 45.783 & 17.200 & $\uparrow 31.477$ & 16.790 & 5.940 \\
\hline & Liver & 65.345 & 28.634 & 98.208 & 10.399 & 120.256 & 10.679 & 37.037 & 7.588 \\
\hline & Gill & 31.010 & 61.737 & 37.109 & $\uparrow 153.790$ & 30.451 & 62.260 & 30.495 & 0.356 \\
\hline \multirow{4}{*}{$\begin{array}{l}\text { SOD activity } \\
\text { (IU SOD/mg protein) }\end{array}$} & Brain & 11.453 & $\uparrow 20.324$ & 11.048 & 11.603 & 12.863 & $\uparrow 15.534$ & 17.243 & 26.567 \\
\hline & Blood & 9.095 & 1.958 & 10.841 & 3.437 & 7.918 & 13.086 & 10.320 & 4.633 \\
\hline & Liver & 41.155 & 7.880 & 33.011 & 7.602 & 76.764 & 2.753 & 15.378 & 13.406 \\
\hline & Gill & 20.490 & 31.114 & 24.650 & $\uparrow 56.657$ & 15.648 & $\uparrow 39.057$ & 10.504 & $\uparrow 32.005$ \\
\hline \multirow{4}{*}{$\begin{array}{l}\text { CAT activity (mM } \\
\mathrm{H}_{2} \mathrm{O}_{2} / \mu \mathrm{g} \text { protein) }\end{array}$} & Brain & 8973.679 & 1195.003 & 14508.806 & $\downarrow 1454.124$ & 4976.454 & $\downarrow 1090.770$ & 13188.581 & 2241.322 \\
\hline & Blood & 4660.100 & 318.900 & 5352.400 & 925.600 & 4175.700 & 600.500 & 4437.600 & 116.600 \\
\hline & Liver & 46700.264 & 219.300 & 54483.800 & 130.100 & 119631.100 & 313.700 & 22044.473 & 1284.330 \\
\hline & Gill & 12120.900 & $\downarrow 510.700$ & 21118.770 & 670.800 & 16536.700 & 535.900 & 15096.700 & $\downarrow 3119.200$ \\
\hline \multirow{4}{*}{$\begin{array}{l}\text { GPx activity } \\
\text { (mM NADPH/ } \\
\text { mg protein) }\end{array}$} & Brain & 0.001 & 0.006 & 0.003 & $\downarrow 0.001$ & 0.006 & $\uparrow 0.026$ & 0.001 & 0.004 \\
\hline & Blood & 0.001 & $\downarrow 0.001$ & 0.001 & 0.022 & 0.001 & 0.002 & 0.001 & 0.003 \\
\hline & Liver & 0.005 & $\uparrow 0.000$ & 0.016 & $\downarrow 0.001$ & 0.078 & $\downarrow 0.001$ & 0.004 & $\uparrow 0.002$ \\
\hline & Gill & 0.002 & 0.012 & 0.004 & $\uparrow 0.030$ & 0.005 & $\uparrow 0.020$ & 0.002 & 0.016 \\
\hline $\begin{array}{l}\text { Micronucleus test } \\
\text { (Micronuclei/ } \\
1000 \text { cells) }\end{array}$ & Blood & 82.667 & 164.333 & 122.667 & 107.333 & 359.667 & 120.667 & 116.333 & $\downarrow 33.667$ \\
\hline $\begin{array}{l}\text { Comet Assay } \\
\text { (damage index) }\end{array}$ & Blood & 2.482 & $\downarrow 1.395$ & 2.773 & 1.513 & 3.111 & $\downarrow 1.621$ & 2.979 & 1.608 \\
\hline $\begin{array}{l}\text { Caspase-3 } \\
\text { ((nM free pNA/h)/ } \\
\mu \mathrm{g} \text { protein) }\end{array}$ & Blood & 1090.641 & 305.338 & 605.161 & $\downarrow 306.278$ & 331.277 & 140.716 & 790.636 & 277.824 \\
\hline
\end{tabular}

$\mathrm{LPX}=$ lipid peroxidation, $\mathrm{MDA}=$ malondialdehyde, $\mathrm{SOD}=$ superoxide dismutase, $\mathrm{CAT}=$ catalase, $\mathrm{GPx}=$ glutathione peroxidase, $\mathrm{pNA}=p$-nitroanilid; Additive interaction is the calculated value and result of the sum of the effect determined for the DCF and IBP by themselves, the actual value is the effect produced by the mixture DCF-IBP and experimentally determined in the study. ANOVA and Bonferroni. Up arrow and down arrow indicates a decrement or increment respect to additive interaction.

placed in order to ensure no exposure to pharmaceuticals occurred in the control group. Systems were maintained at room temperature with a natural light/dark photoperiod and provided with constant aeration. A time dependent exposure series was run for the following exposure periods: $12,24,48,72$, and $96 \mathrm{~h}$. At the end of the exposure period, IBP and DCF were quantified in exposure system water.

IBP and DCF concentrations were determined using an Agilent 1290 Infinity HPLC unit (Santa Clara CA). The Eclipse Plus C18 RRHD $(2.1 \times 50 \mathrm{~mm}, 1.8 \mu \mathrm{m})$ chromatographic column was maintained at $40^{\circ} \mathrm{C}$. The mobile phase employed was a $60: 40 \mathrm{v} / \mathrm{v}$ (IBP) and a 50:50 $\mathrm{v} / \mathrm{v}$ (DCF) mixture of acetonitrile and ammonium formate $(10 \mathrm{mM}$,

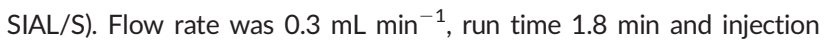
volume $2 \mu \mathrm{L}$, IBP and DCF were identified and quantified with an Agilent 6430 Triple Quadrupole mass spectrometer (MS) equipped with electrospray ionization (ESI). The ESI positive mode was used throughout. Electrospray voltage operated at $4000 \mathrm{~V}$ as the MS collected data in the negative ion mode. MS optimization was conducted by direct infusion of a $10 \mu \mathrm{gL}^{-1}$ standard solution of IBP or DCF; thereafter, the ionization mode and precursor ion mode were selected.

Five-milliliter water samples from exposure glass tanks were collected in glass sample vials and refrigerated at $4^{\circ} \mathrm{C}$ for subsequent measurement of test concentrations. The results are expressed as timeweighted average concentrations of IBP and DCF. Samples were acidified with $1 \mathrm{M} \mathrm{HCl}$ and extraction with $5 \mathrm{~mL}(1+1)(\mathrm{v} / \mathrm{v})$ hexane/ethyl acetate was conducted to extract IBP and DCF from 1-mL water samples. These samples were centrifuged at $1800 \times \mathrm{g}$ for $10 \mathrm{~min}$, and then the upper organic layer was re-extracted. Extraction was repeated until the organic layers combined and evaporated to dryness.

\subsection{Statistical analysis}

In the acute toxicity assays (96-h LC 50 of IBP and DCF), Probit analysis was performed and significance assessed by the degree of $95 \% \mathrm{LC}_{50}$ overlap (EPA Analysis Program v3.3; US-EPA, 2013). 


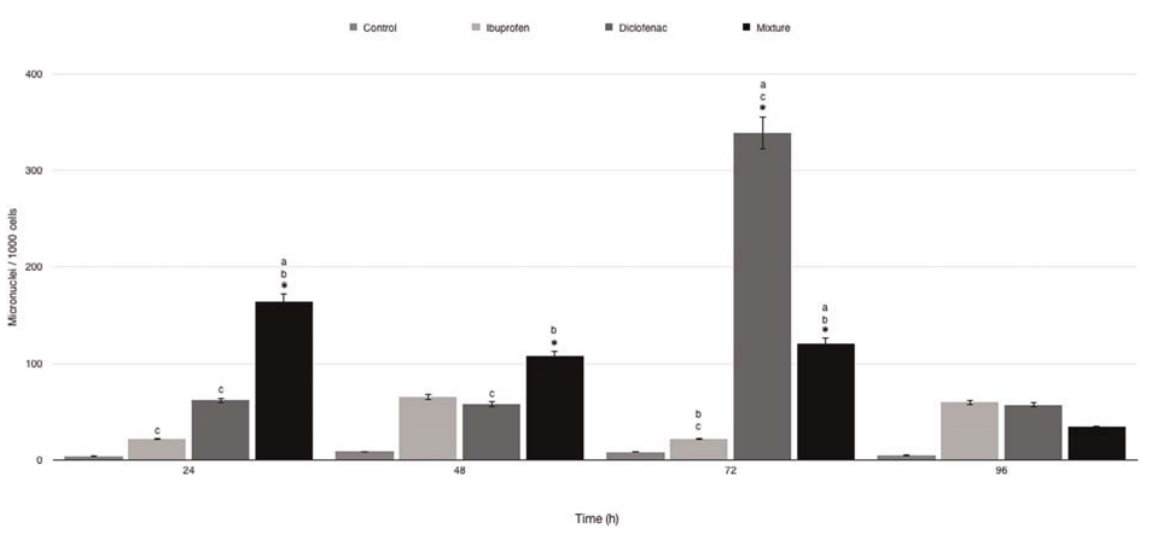

FIGURE 2 Blood levels of micronuclei in C. carpio exposed to ibuprofen and diclofenac in isolated form and as a mixture. Values are the mean $\pm \mathrm{SE}$. *Significantly different from control group. Lowercase letters indicate a significant difference relative to specimens exposed to $a_{\text {ibuprofen, }}{ }^{b}$ diclofenac, and ${ }^{c}$ the binary mixture $(P<0.05)$, ANOVA and Bonferroni

Results of oxidative stress biomarkers, $\mathrm{MNi}$, comet assay and the specific activity of caspase- 3 were evaluated by one-way analysis of variance (ANOVA) and differences between means were compared using the Bonferroni multiple comparisons test, with $P$ set at $<0.05$. Pearson's correlation analysis was used to examine potential correlations between IBP and DCF concentrations present in water from binary mixture exposure systems and the biomarkers evaluated in different tissues of the mixture IBP-DCF. Statistical determinations were made with SPSS v10 (SPSS, Chicago IL).

\section{3 | RESULTS}

\section{1 | Determination of $\mathrm{LC}_{50}$}

The 96-h LC 50 of IBP in C. carpio was $175.6 \mathrm{mg} \mathrm{L}^{-1}$ with a $95 \%$ confidence interval of (107.31-334.05 $\left.\mathrm{mg} \mathrm{L}^{-1}\right)$. The corresponding values for DCF were $70.98 \mathrm{mg} \mathrm{L}^{-1}$ and $\left(51.66-98.14 \mathrm{mg} \mathrm{L}^{-1}\right)$. The $\chi^{2}$ linear adjustment test was not significant at $P<0.05$.

\section{2 | Sublethal toxicity assays}

\subsection{1 | Evaluation of oxidative stress}

\subsubsection{1 | LPX}

A significant increase in LPX compared to the control group $(P<0.05)$ occurred with IBP alone in blood at 24 and $48 \mathrm{~h}$, in liver at 24,48 , and $72 \mathrm{~h}$, and in gill at 48 and $96 \mathrm{~h}$. In specimens exposed to DCF alone, LPX increased in liver at $24 \mathrm{~h}$ and in gill at 48 and $72 \mathrm{~h}$, while in those exposed to the mixture LPX increased in liver at 24 and $96 \mathrm{~h}$, and in brain and blood at all exposure times, the highest values of LPX occurring in gills of the binary mixture at all time period. A significant reduction in LPX was found with IBP in brain at $24 \mathrm{~h}$; with DCF in brain at $24 \mathrm{~h}$, in blood at 24, 72, and $96 \mathrm{~h}$, and in liver at $96 \mathrm{~h}$; and with the mixture in liver at 48 and $72 \mathrm{~h}$ (Figure 1).

\subsubsection{2 | SOD activity}

Significant increases with respect to the control group $(P<0.05)$ occurred with IBP alone in blood and liver at $24 \mathrm{~h}$, and in gill at 24,48 , and $96 \mathrm{~h}$; with DCF alone in liver at $24 \mathrm{~h}$, and in gill at 24 and $48 \mathrm{~h}$;

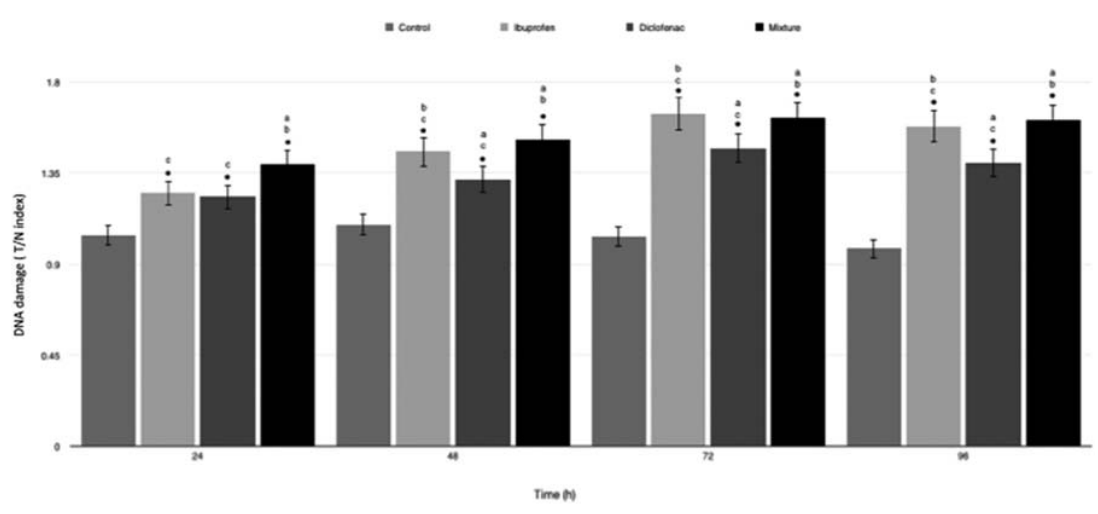

FIGURE 3 DNA damage determined by comet assay in C. carpio exposed to ibuprofen and diclofenac in isolated form and as a mixture. Values are the mean \pm SE. ${ }^{*}$ Significantly different from control group. Lowercase letters indicate a significant difference relative to specimens exposed to ${ }^{a}$ ibuprofen, ${ }^{b}$ diclofenac, and ${ }^{c}$ the binary mixture $(P<0.05)$, ANOVA and Bonferroni 


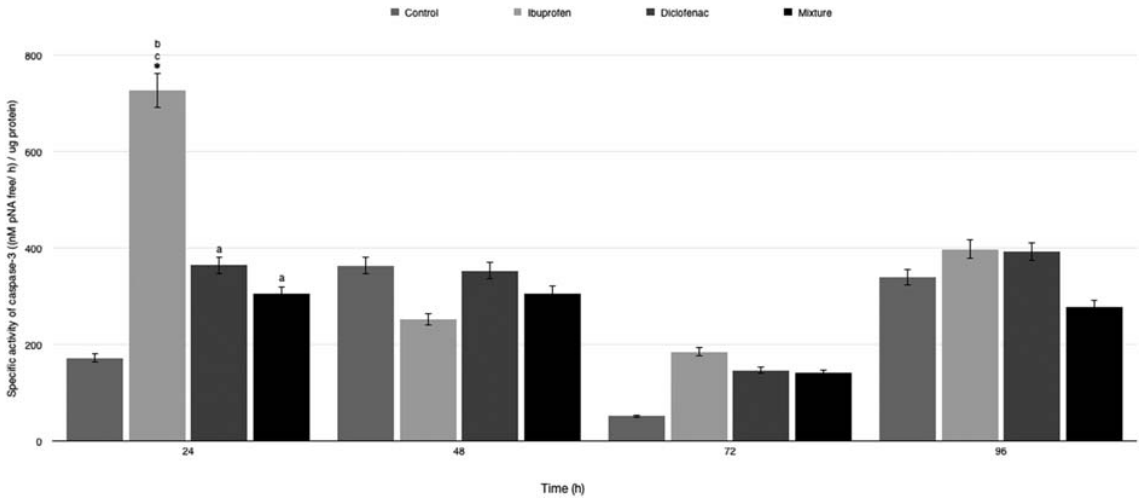

FIGURE 4 Specific activity of caspase-3 in blood of $C$. carpio exposed to ibuprofen and diclofenac in isolated form and as a mixture. Values are the mean $\pm \mathrm{SE}$. pNA $=p$-nitroanilide. ${ }^{*}$ Significantly different from control group. Lowercase letters indicate a significant difference relative to specimens exposed to ${ }^{a}$ ibuprofen, ${ }^{b}$ diclofenac, and ${ }^{c}$ the binary mixture $(P<0.05)$, ANOVA and Bonferroni

and with the binary mixture in brain and gill at all exposure times, in blood at $72 \mathrm{~h}$, and in liver at 24 and $96 \mathrm{~h}$. Significant reductions were observed with DCF in brain at $48 \mathrm{~h}$, and with the mixture in liver at $72 \mathrm{~h}$ (Figure 1). The activity of the gills in the binary mixture significantly increased for all time periods

\subsubsection{3 | CAT activity}

Significant increases $(P<0.05)$ compared to the control group were found with exposure to IBP alone in liver at 24 and $96 \mathrm{~h}$, and in gill at $96 \mathrm{~h}$; and with exposure to DCF alone in liver at $72 \mathrm{~h}$ and in gill at $48 \mathrm{~h}$; while in carp exposed to the mixture significant decreases occurred in brain at 24, 48 and $72 \mathrm{~h}$, in blood at 24, 72, and $96 \mathrm{~h}$, in liver at 24,48 , and $72 \mathrm{~h}$, and in gill at 24,48 , and $72 \mathrm{~h}$ (Figure 1).

\subsubsection{GPx activity}

Significant increases with respect to the control group $(P<0.05)$ occurred with DCF alone in liver at $72 \mathrm{~h}$; and with the binary mixture in brain at 24, 72, and $96 \mathrm{~h}$, and in blood at $48 \mathrm{~h}$, the highest increases being observed in gill of the mixture at all exposure times. Significant reductions were found with IBP in liver at $24 \mathrm{~h}$; with DCF in gill at $96 \mathrm{~h}$; and with the mixture in liver at 24,48 , and $72 \mathrm{~h}$ (Figure 1).

Table 1 shows the additive interaction values (calculated using IBP and DCF in isolated form) and the actual values obtained with each biomarker in specimens exposed to the binary mixture. In most oxidative stress biomarkers, actual values were higher than additive interaction values at all exposure times while in biomarkers of cytogenotoxicity a time-dependent reduction in actual values was found relative to additive interaction values.

\subsection{2 | Evaluation of cyto-genotoxicity}

\subsubsection{Micronucleus test}

$\mathrm{MNi}$ frequency results are shown in Figure 2. Carp exposed to DCF alone evidenced a significant increase in this biomarker at $72 \mathrm{~h} \quad(P<0.05)$ compared to the control group, while in fish exposed to the binary mixture this increase occurred at 24,48 , and $72 \mathrm{~h}$. No significant differences were found with exposure to IBP alone.

\subsubsection{2 | Comet assay}

A significant increase in the damage index compared to the control group $(P<0.05)$ was found at all exposure times in specimens exposed to IBP and DCF in isolated form and as a mixture. This increase was higher with IBP than DCF, while the mixture induced an even higher increase at 24, 48, and $96 \mathrm{~h}$ (Figure 3).

\subsubsection{Specific activity of caspase-3}

Results of the specific activity of caspase-3 are shown in Figure 4. A significant increase with respect to the control group $(P<0.05)$

TABLE 2 Ibuprofen and diclofenac concentrations at the different exposure times in water from single pharmaceutical and binary mixture exposure systems

\begin{tabular}{|c|c|c|c|c|}
\hline $\begin{array}{l}\text { Time } \\
\text { (h) }\end{array}$ & $\begin{array}{l}\text { Single pharmaceut. } \\
\text { IBP }\left(\mathrm{mg} \mathrm{L}^{-1}\right)\end{array}$ & $\begin{array}{l}\text { Single pharmaceut. } \\
\text { DCF }\left(\mathrm{mg} \mathrm{L}^{-1}\right)\end{array}$ & $\begin{array}{l}\text { Binary mixture } \\
\text { IBP }\left(\mathrm{mg} \mathrm{L}^{-1}\right)\end{array}$ & $\begin{array}{l}\text { Binary mixture } \\
\text { DCF }\left(\mathrm{mg} \mathrm{L}^{-1}\right)\end{array}$ \\
\hline 0 & $17.56 \pm 0.98$ & $7.10 \pm 0.35$ & $17.56 \pm 0.02$ & $7.10 \pm 0.05$ \\
\hline 24 & $13.17 \pm 1.08$ & $1.77 \pm 0.13$ & $11.39 \pm 0.02^{*}$ & $3.55 \pm 0.05^{*}$ \\
\hline 48 & $12.29 \pm 0.79$ & $1.61 \pm 0.06$ & $11.01 \pm 0.02^{*}$ & $3.31 \pm 0.05^{*}$ \\
\hline 72 & $11.41 \pm 0.56$ & $1.52 \pm 0.06$ & $10.64 \pm 0.02$ & $2.59 \pm 0.05^{*}$ \\
\hline 96 & $10.53 \pm 0.91$ & $1.39 \pm 0.06$ & $2.63 \pm 0.02^{*}$ & $2.01 \pm 0.05$ \\
\hline
\end{tabular}

Values are the mean of five replicates $\pm \mathrm{SE}$. IBP $=$ ibuprofen, $\mathrm{DCF}=$ diclofenac. *Significantly different from single pharmaceutical exposure systems $(P<0.05)$, ANOVA, and Bonferroni. 
TABLE 3 Pearson's correlation between biomarker values in the different tissues of $C$. carpio exposed to the mixture and ibuprofen and diclofenac concentrations in water from binary mixture exposure systems, at the various exposure times

\begin{tabular}{|c|c|c|c|c|c|c|c|c|c|}
\hline \multirow[t]{2}{*}{$\begin{array}{l}\text { Biomarkers } \\
\text { determinated } \\
\text { in the mixture }\end{array}$} & \multirow{2}{*}{ Tissue } & \multicolumn{4}{|c|}{$\begin{array}{l}\text { IBP } \\
\text { concentration in water from binary mixture } \\
\text { exposure systems }\end{array}$} & \multicolumn{4}{|c|}{$\begin{array}{l}\text { DCF concentration in water from binary mixture } \\
\text { exposure systems }\end{array}$} \\
\hline & & $24 \mathrm{~h}$ & $48 \mathrm{~h}$ & $72 \mathrm{~h}$ & $96 \mathrm{~h}$ & $24 \mathrm{~h}$ & $48 \mathrm{~h}$ & $72 \mathrm{~h}$ & $96 \mathrm{~h}$ \\
\hline \multirow[t]{4}{*}{ LPX } & Brain & 0.927 & -0.693 & -0.866 & 0.998 & 0.927 & -0.693 & -0.897 & 0.998 \\
\hline & Blood & 0.908 & -0.839 & -0.956 & 0.908 & 0.908 & -0.840 & -0.681 & 0.908 \\
\hline & Liver & 0.874 & 0.927 & -0.680 & -0.844 & 0.875 & 0.927 & -0.225 & -0.844 \\
\hline & Gill & 0.936 & 0.998 & 0.927 & -1.000 & 0.936 & 0.998 & 0.990 & -1.000 \\
\hline \multirow{4}{*}{$\begin{array}{l}\text { SOD } \\
\text { activity }\end{array}$} & Brain & -0.931 & -0.885 & -0.879 & -0.853 & -0.931 & -0.885 & -0.999 & -0.853 \\
\hline & Blood & 0.889 & -0.815 & 0.880 & -0.862 & 0.836 & 0.889 & -0.815 & 0.999 \\
\hline & Liver & 0.327 & 0.879 & -0.860 & -0.858 & 0.327 & 0.879 & -0.999 & -0.858 \\
\hline & Gill & 0.921 & 0.985 & 0.985 & -0.485 & 0.921 & 0.985 & 0.939 & 1.000 \\
\hline \multirow{4}{*}{$\begin{array}{l}\text { CAT } \\
\text { Activity }\end{array}$} & Brain & 0.588 & -0.795 & 0.240 & -0.857 & 0.588 & -0.795 & -0.277 & -0.857 \\
\hline & Blood & 0.777 & -0.993 & 0.465 & 0.961 & 0.777 & -0.993 & -0.401 & 0.961 \\
\hline & Liver & 0.601 & -0.655 & -0.327 & 0.682 & 0.601 & -0.655 & -0.756 & 0.682 \\
\hline & Gill & -0.945 & 0.997 & 0.240 & 1.000 & -0.945 & 1.000 & -0.277 & 1.000 \\
\hline \multirow{4}{*}{$\begin{array}{l}\text { GPx } \\
\text { Activity }\end{array}$} & Brain & 0.993 & 0.913 & -0.844 & 1.000 & 0.993 & 0.913 & -0.999 & 1.000 \\
\hline & Blood & 0.433 & -0.397 & -0.997 & 0.577 & 0.433 & -0.397 & -0.822 & 0.577 \\
\hline & Liver & 0.676 & -0.572 & -0.153 & -0.964 & 0.676 & -0.572 & 0.362 & -0.096 \\
\hline & Gill & -0.101 & 0.115 & 0.554 & -0.240 & -0.101 & 0.115 & 0.896 & -0.240 \\
\hline Micronuclei & Blood & 0.322 & -0.056 & 0.101 & -0.915 & 0.322 & -0.558 & 0.585 & -0.915 \\
\hline Comet Assay & Blood & 0.943 & -0.983 & -0.936 & 0.999 & 0.496 & 0.894 & 0.553 & 0.999 \\
\hline Caspase-3 & Blood & 0.885 & -0.173 & 0.575 & 0.218 & 0.885 & -0.173 & -0.449 & 0.218 \\
\hline
\end{tabular}

Significant correlations $(P<0.05)$ are shown in bold. A minus sign denotes a positive correlation (high values in one set correlate with high values in the other); its absence denotes a negative correlation (low values in one set correlate with high values in the other). Values near zero indicate that factors are unrelated. IBP = ibuprofen, $\mathrm{DCF}=$ diclofenac, $\mathrm{LPX}=$ lipid peroxidation, $\mathrm{SOD}=$ superoxide dismutase, $\mathrm{CAT}=$ catalase, $\mathrm{GPx}=\mathrm{glutathione}$ peroxidase.

occurred only with IBP alone at $24 \mathrm{~h}$; values in specimens exposed to DCF alone or to the binary mixture did not differ significantly from control group values.

\subsection{IBP and DCF quantification}

Table 2 lists IBP and DCF concentrations in water from exposure systems containing these pharmaceuticals in isolated form or as a mixture. In systems with either pharmaceutical alone, NSAID concentration decreased over time. A similar behavior was observed in systems with the binary mixture; however, at $96 \mathrm{~h}$, IBP concentration was markedly lower in binary mixture systems than in those with IBP alone. In the control group DCF and IBP was not observed.

Table 3 shows correlation results between biomarker values in tissues of specimens exposed to the binary mixture of IBP and DCF, with the IBP and DCF concentrations in water from binary mixture exposure systems, at the various exposure times. As can be seen, very close correlations exist between biomarker values and pharmaceutical concentrations in water from exposure systems.

\section{4 | DISCUSSION}

The 96-h LC Lo $_{50}$ of IBP in C. carpio was $175.56 \mathrm{mg} \mathrm{L}^{-1}$ in this study while the corresponding value for DCF was $70.98 \mathrm{mg} \mathrm{L}^{-1}$. In other fish species, the $\mathrm{LC}_{50}$ of IBP has been reported as $173.0 \mathrm{mg} \mathrm{L}^{-1}$ in Lepomis macrochirus ${ }^{2}$ and $142 \mathrm{mg} \mathrm{L}^{-1}$ in Cirrhinus mrigala, while the $\mathrm{LC}_{50}$ of DCF in juvenile Danio rerio ranged from 156.8 to $176.4 \mathrm{mg}$ $\mathrm{L}^{-152}$. In our study and in others in which different species were used, DCF LC $_{50}$ values are lower than those of IBP. Therefore, DCF can be considered to be more toxic than IBP. This difference may be due to different biotransformation metabolites; in various studies, it has shown that IBP and DCF may undergo suffer biotic and abiotic reactions. In fish, diverse P450 enzymes in the smooth endoplasmic reticulum of cells in the liver, kidneys, gills, gut, brain, heart, and gonads, among other organs, are able to biotransform xenobiotics. ${ }^{53}$ In humans, the CYP2C9 family is known to mediate the biotransformation of IBP and DCF by hydroxylation to 2- or 3hydroxyibuprofen and 4-hydroxydiclofenac, respectively, ${ }^{54,55}$ while the families CYP2C8, CYP2C18, CYP2C19, and CYP2B6 mediate DCF biotransformation to 5-hydroxydiclofenac. ${ }^{56}$ Gomez et al. ${ }^{57}$ noted that 2-hydroxyibuprofen was the major metabolite identified 


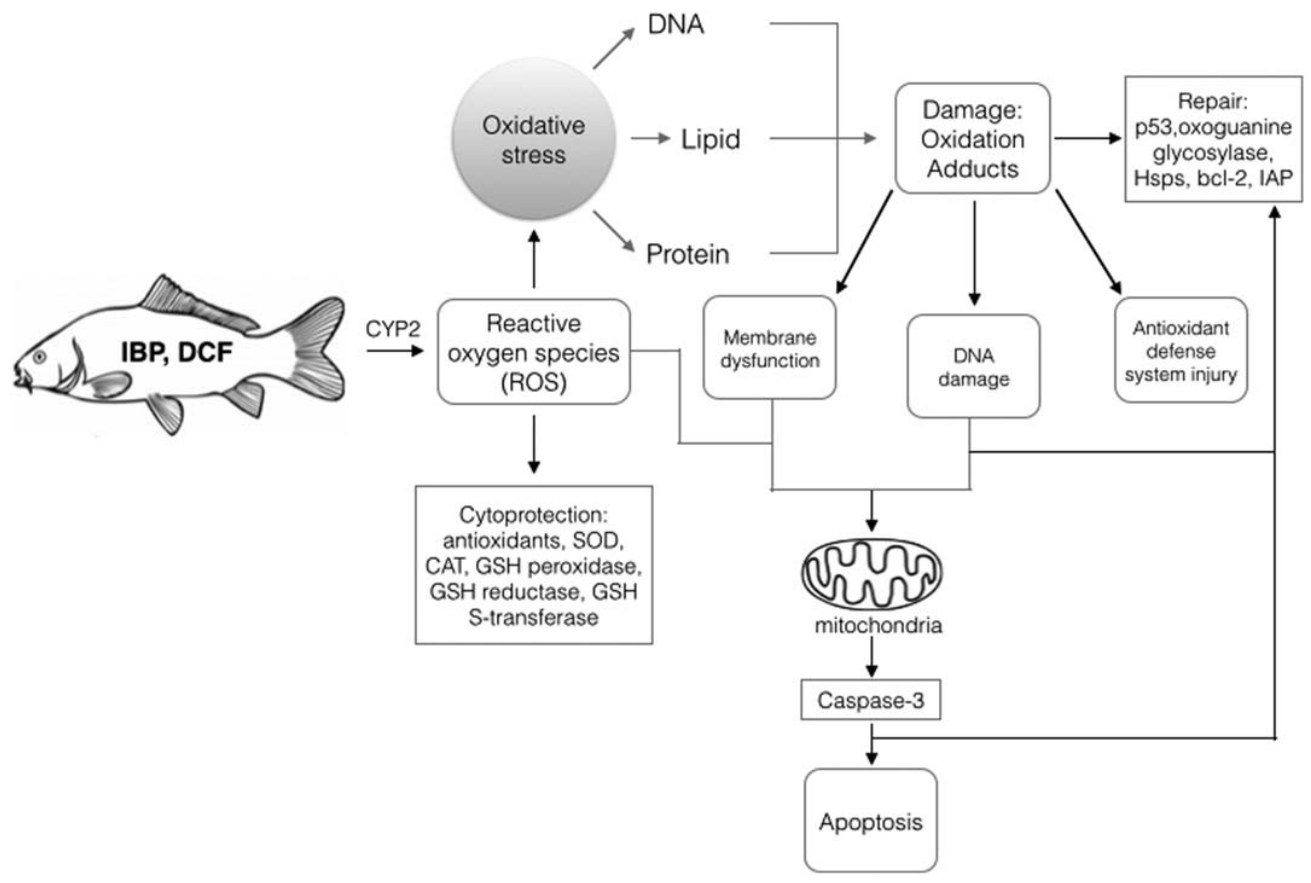

FIGURE 5 Proposed mechanisms of ibuprofen- and diclofenac-induced toxicity in C. carpio. CAT: catalase; DCF: diclofenac; GSH: glutathione; HSP: heat shock protein; IAP: inhibitor of apoptosis protein; IBP: ibuprofen; SOD: superoxide dismutase

in in vitro metabolism studies on fish, while Hoeger et al. ${ }^{24}$ showed that DCF inhibits COX activity and therefore prostaglandin E2 synthesis in brown trout head kidney macrophages in vitro, thus confirming the existence in fish of the same mode of action reported previously in mammalian species. Also, IBP and DCF-derived acyl glucuronides have been shown to form covalent bonds with both intraand extracellular proteins, with toxicological consequences. ${ }^{58}$ In addition to biotic transformations, in water bodies, these pharmaceuticals may be photodegraded in the presence of light or biodegraded by micro-organisms to smaller, more hydrophobic and more toxic molecules. The main metabolites of IBP resulting from these processes include 4-isobutylacetophenone, 1-(6-methoxy-2-naphthyl) ethanol and 2-acetyl-6-methoxynaphthalene while those of DCF are 5,4'dihydroxydiclofenac, 3-dihydroxydiclofenac, 4'-dihydroxymethyldiclofenac, 3'-hydroxymethyl-diclofenac, 4'-hydroxydiclofenac and $5^{\prime}$ hydroxydiclofenac. ${ }^{59}$ The latter two are oxidized to benzoquinone imine intermediates, compounds that are highly toxic to aquatic organisms, ${ }^{30}$ and therefore, the high DCF toxicity in this study could be the result this intermediates.

As can be seen in Table 2, IBP and DCF concentrations in our study decreased over time in water from single pharmaceutical exposure systems. However, in water from binary mixture exposure systems, IBP concentration decreased faster and reaches a lower concentration than in the single pharmaceutical system, while DCF concentration decreased more slowly, suggesting that these NSAIDs may have interactions in the mixture that favor the loss of IBP in the system. Furthermore, as evidenced in Table 3, these concentrations in water exposure systems can be correlated with the results obtained for different biomarkers evaluated.
A state of oxidative stress occurs when exist an excess of prooxidants that cannot be counteracted by antioxidants systems. LPX impairs biomembrane function, decreases membrane fluidity, inactivates membrane-bound enzymes and receptors, and can change selective permeability to calcium ions ${ }^{60}$, it involves a chain of redox reactions, particularly in polyunsaturated fatty acids, which are highly sensitive to ROS-induced oxidation due to the presence of double bonds in their structure ${ }^{61}$. In Figure 1, the amount of MDA produced was higher in specimens exposed to the binary mixture than in those exposed to IBP or DCF alone; brain and gill being the tissues with the most LPX-induced damage. Increased LPX particularly in brain and gill was also found by Nava-Álvarez et al. ${ }^{62}$ in C. carpio exposed to a mixture of DCF and acetaminophen. In phase I, biotransformation of NSAIDs, CYP produces an oxygenated intermediate-the oxycytochrome P450 complex $\left[\mathrm{P} 450\left(\mathrm{Fe}^{3+}\right) \mathrm{O}_{2}^{-}\right]$-with subsequent release by reaction decoupling of superoxide anion, an oxidant species that damages membrane lipids, ${ }^{63}$ besides the generation of the aforementioned reactive metabolites and intermediates, on the other hand, since NSAIDs affect the mitochondrion and therefore oxidative phosphorylation, increased ROS production may occur, particularly of $\mathrm{O}_{2-}$, and as a result, an increase in LPX, and these processes may be explained the increase found. To mitigate the negative effects of ROS, fish-like other vertebrates-possess an antioxidant defense system. Antioxidant defenses are induced by environmental contaminants under prooxidant conditions. The main enzymatic antioxidant is SOD, these include the manganese-complexed enzyme in mitochondria (MnSOD) and the copper/zinc-complexed enzyme (CuZnSOD) present in the cytosol and extracellular surfaces. ${ }^{64} \mathrm{SOD}$ catalyzes the conversion of superoxide anion $\left(\mathrm{O}_{2}\right)$ to hydrogen peroxide $\left(\mathrm{H}_{2} \mathrm{O}_{2}\right),{ }^{65}$ which is metabolized to $\mathrm{O}_{2}$ 
and water by CAT, associated primarily with peroxisomes and detoxification, ${ }^{66}$ and GPx. ${ }^{35}$ In our study, the binary mixture of IBP and DCF induced a higher increase in SOD activity than either pharmaceutical alone (Figure 1). It is therefore inferred that, particularly in brain and gill, SOD counteracts LPX-induced damage. The increased SOD activity found may be explained by the fact that both IBP and DCF oxidative metabolism favor formation of the anion radical $\mathrm{O}^{2 *}{ }^{63}$ Similar results were obtained in the freshwater bivalve Dreissena polymorpha exposed to a mixture of DCF, IBP, and PAR. In our study (Figure 1), CAT activity decreased in groups exposed to the mixture, the lowest values being recorded in liver. This decrease may be due to overproduction of $\mathrm{H}_{2} \mathrm{O}_{2}$. GPx is a cytosolic enzyme and the most important peroxidase that reacts with $\mathrm{H}_{2} \mathrm{O}_{2}$, reducing it to $\mathrm{H}_{2} \mathrm{O}$ and alcohol using $\mathrm{GSH}$ as a reducing agent. ${ }^{67,68}$ In this study, GPx activity was highest in gill and brain (Figure 1), as was also the case with SOD activity (Figure 1), possibly showing that these enzymes act at the cytosol of cells reducing $\mathrm{H}_{2} \mathrm{O}_{2}$ formed from the reaction of SOD. Bagnyukova et al. ${ }^{69}$ report that LPX products are apparently involved in the regulation of antioxidant enzymes. Thus, increased ROS production in this study may also explain the increased SOD, CAT, and GPx activity observed.

Monitoring of clastogenic effects of pollutants is of primary interest in aquatic environmental mutagenesis for determining the pollution-related stress in living organisms. ${ }^{70} \mathrm{MNi}$ test with fish has been shown to be a useful in vivo technique for genotoxicity testing, $\mathrm{MNi}$ are chromosome fragments or whole chromosomes that are not included in the main nucleus, and are seen as small nuclei in the cytoplasm of cells in interphase. ${ }^{71} \mathrm{MNi}$ arise in peripheral blood erythrocytes as a result of DNA damage to cells mainly in the S-stage of interphase. In our study, the binary mixture induced significant increases in $\mathrm{MNi}$ at 24,48 , and $72 \mathrm{~h}$, although peak values were recorded with DCF alone at $72 \mathrm{~h}$ (Figure 2). This behavior-i.e., $\mathrm{MNi}$ values increasing during early exposure times and decreasing thereafter-has been observed in other species exposed to different genotoxic agents. A decrease in $\mathrm{MNi}$ numbers after a phase of increase depends on the type of genotoxic concentration used, manner of administration, and genetic response in each species. ${ }^{47,72,73}$ The increase in $\mathrm{MNi}$ found in this study may be due to breakage of DNA and/or chromosome mis-segregation, events resulting from aneugenic and clastogenic effects elicited by ROS and some xenobiotics, including $\mathrm{DCF}$ and $\mathrm{IBP} .{ }^{74}$ ROS production has been shown to induce singlestrand breaks and base modifications, ${ }^{75}$ which may explain the increased $\mathrm{MNi}$ frequency and damage index results found in the present study. On the other hand, the decrease observed at $96 \mathrm{~h}$ in $\mathrm{MNi}$ could be due to an increased antioxidant activity, mainly of SOD and GPx activity, of the organisms in response to oxidant damage, which is evident in Figure 1. Comet assay results in this study show that significant damage was induced in all exposed groups at all exposure times, a higher rate of damage being induced by the mixture (Figure 3). In the DNA molecule, the nucleophilic groups of deoxyribose and nitrogenous bases are exposed to electrophilic attack by ROS which reach the cell nucleus and are formed as a result of external agents or cellular metabolic processes. ${ }^{76}$ Different types of oxidative DNA damage have been reported, including single or double-strand breaks in the sugarphosphate backbone, modification of nitrogenous bases (thymine ring saturation and fragmentation) and formation of DNA-protein or DNADNA crosslinks through diverse mechanisms: modification of DNA bases $-\mathrm{OH}$ radical action leads to over 20 modifications, the most common being 8-hydroxy-2'-deoxyguanosine (8-OHdG) which has high mutagenic potential like 5-hydroxymethyl-2'-deoxyuridinedepurination of DNA bases (apurinic or apyrimidinic sites formed by cleavage of the glycosidic bond, which may result from $\mathrm{OH}$. radical attack on sugar), and strand breaks (due to cleavage of the phosphodiester bond, occurring frequently by free radical attack on deoxyribose of the DNA backbone). ${ }^{77}$

Cytotoxicity is a change in basic cell functions leading to damage that can be detected. Apoptosis or programed cell death is an ATPdependent active process, characterized by breaking of the cell into apoptotic bodies, nuclear condensation, and caspase activation, which does not affect neighboring cells. There are two main routes to apoptotic death: the extrinsic pathway, initiated by the binding of specific cell membrane receptors and resulting in activation of caspase- 8 which begins the cascade activation of other molecules leading to cell death; and the intrinsic pathway, initiated by rupture of the mitochondrial membrane and formation of pores through which caspase- 9 activating factors (cytochrome c) are released, initiating the cascade leading to death by apoptosis; it should be noted that both pathways in turn lead to the activation of the main effector caspase, caspase 3 , which degrades other protein substrates into the cells to trigger apoptotic processes. ${ }^{78}$ In our study (Figure 4), IBP alone at $24 \mathrm{~h}$ was the only factor inducing a significant increase in the specific activity of caspase 3 . Since COX inhibition is the mechanism of action of NSAIDs, it has been suggested that decreased cellular levels of prostaglandin E2 (PGE2) and increased levels of arachidonic acid may be involved in inhibition of cell proliferation and induction of apoptosis. ${ }^{79}$ An increase in the cellular concentration of arachidonic acid can alter mitochondrial membrane permeability and elicit cytochrome $\mathrm{c}$ release, leading to apoptosis. ${ }^{80,81}$ Arachidonic acid also increases the production of ceramide, a potent apoptosis inducer. ${ }^{82}$ Diverse studies suggest that increased ROS formation, a deficit in antioxidant defenses, decreased DNA repair mechanism efficiency, proteolysis and loss of immune system regulation contribute to increased oxidative stress. ${ }^{83}$ Also, protein changes such as carbonylation, nitration, and protein-protein crosslinking are generally related to loss of function and can lead on the one hand to splitting and degradation of damaged proteins and on the other to formation of aggregates resulting in protein accumulation, cytoplasmic inclusions, and eventual cell death ${ }^{84}$. Any stressful stimulus (exposure to ROS, DNA damage, or increased extracellular calcium induced by prostaglandin inhibition) can initiate the intrinsic pathway of apoptosis, inducing changes in mitochondrial membrane permeability and edema leading to reduced membrane potential and release of cytochrome c, which binds to Apaf-1, which in turn uses ATP to activate caspase 9 . The latter activates the effector caspase 3 , which hydrolyzes specific substrates leading eventually to cell death. All of these, may explain the increase observed in the specific activity of caspase 3 during early 
exposure times in our study; while the decrease may be due to the fact that the cell also possesses anti-apoptotic proteins ( $\mathrm{Bcl}-2)$, inhibitor of apoptosis proteins (IAPs) and heat shock proteins (HSPs), which act at different levels of the apoptosis cascade preventing its activation; addition to antioxidant enzymes that prevent oxidative damage in cells whose increase can also be seen at different exposure times.

Based on the results observed in this study, we can assume that the IBP and DCF in contact with C. carpio, are biotransformed, especially by the family of cytochrome CYP2, generating ROS, which if not counteracted by different cellular mechanisms of antioxidant protection, can generate a state of oxidative stress, which may result in oxidative damage and adducts at DNA, lipid, and protein level, causing dysfunction in cell membranes, DNA damage, and antioxidant defense system lesions. If damage to the membrane or the DNA is severe, it can activate the intrinsic pathway in the mitochondria which subsequently initiates the cascade that leads to the activation of the main effector caspase, caspase 3, and cell death by apoptosis, which can be inhibited, or possibly repaired by different cellular mechanisms (Figure 5).

\section{5 | CONCLUSIONS}

Our results show that may be a correlation between the loss of NSAID concentrations in water systems and biomarkers evaluated over exposure time. It is therefore proposed that DCF and IBP both in isolated form and as a mixture induce free radicals, oxidative stress, and cytogenotoxicity in tissues of C. carpio. Induced effects are greater with the binary mixture than with either pharmaceutical alone, particularly in gill, and it is possible to infer that potentiation interactions take place between DCF and IBP, while antagonistic interactions occur in biomarkers of cyto-genotoxicity This study provides evidence of oxidative stress and cyto-genotoxicity as a result of sublethal exposure to NSAIDs in the common carp.

\section{ACKNOWLEDGMENTS}

This study was made possible by support from the Secretaria de Investigación y Estudios Avanzados de la UAEM (Project 3722/ 2014CID).

\section{REFERENCES}

[1] Daughton C, Ternes T. Pharmaceuticals and personal care products in the environment: agents of subtle change? Environ Health Perspect. 1999;107:907-938.

[2] Halling-Sørensen B, Nielsen SN, Lanzky PF, Ingerslev F, Lützhøft HC, Jørgensen SE. Ocurrence, fate and effects of pharmaceutical substances in the environment - a review. Chemosphere. 1998;36: 357-393.

[3] Kümmerer K. 2004. Pharmaceuticals in the Environment: Sources, Fate, Effects and Risks. 2nd ed. New York: Springer; 2004.

[4] Stackelberg PE, Furlong ET, Meyer MT, Zaugg SD, Henderson AK, Reissman DB. Persistence of pharmaceutical compounds and other organic wastewater contaminants in a conventional drinking-watertreatment plant. Sci Total Environ. 2004;329:99-113.
[5] Richardson SD, Plewa MJ, Wagner ED, Schoeny R, DeMarini DM. Occurrence, genotoxicity, and carcinogenicity of regulated and emerging disinfection by-products in drinking water: a review and roadmap for research. Mutat Res. 2007;636:178-242.

[6] Takagi T, Ramachandran C, Bermejo M, Yamashita S, Yu LX, Amidon GL. A provisional biopharmaceutical classification of the top 200 oral drug products in the United States, Great Britain, Spain and Japan. Mol Pharmacol. 2006;3:631-643.

[7] Parolini M, Binelli A, Cogni D, Riva C, Provini A. An in vitro biomarker approach for the evaluation of the ecotoxicity of nonsteroidal anti-inflammatory drugs (NSAIDs). Toxicol Vitro. 2009;23: 935-942.

[8] Secretaría de Economía. Industria Farmacéutica Unidad de Inteligencia de Negocios. 2013; http://www.promexico.gob.mx/work/models/comercio/Resource/127/1/images/FC_Farmaceutica_ESP.pdf. Accessed January 17, 2016.

[9] Hardman JG, Limbird LE, Goodman A. Las Bases Farmacológicas De La Terapéutica. 10th ed. Mexico DF: McGraw-Hill Interamericana; 2003.

[10] Morrow JD, Roberts LJ. Lipid-derived autacoids: eicosanoids and platelet-activating factor. In: Hardman JG, Limbird LE, eds. Goodman and Gilman's the Pharmacological Basis of Therapeutics. New York: McGraw-Hill; 2001:669-686.

[11] Katzung B. Farmacología Básica Y Clínica. 9th ed. Mexico DF: Manual Moderno; 2007.

[12] Bendz D, Paxéus NA, Ginn TR, Loge FJ. Occurrence and fate of pharmaceutically active compounds in the environment, a case study: Höje River in Sweden. J Hazard Mater. 2005;122:195-204.

[13] Carlsson C, Johansson A, Alvan G, Bergman, Kuhler T. Are pharmaceuticals potent environmental pollutans? Part I: Environmental risk assessment of selected active pharmaceuticals ingredients. Sci Total Environ. 2006;364:67-87.

[14] Ferrari B, Paxéus N, Giudice RL, Pollio A. Ecotoxicological impact of pharmaceuticals found in treated wastewaters; study of carbamazepine, clofibric acid, and diclofenac. Ecotoxicol. Environ Safe. 2003; 55:359-370.

[15] Kolpin DW, Furlong ET, Meyer MT, et al. Pharmaceuticals, hormones, and other organic wastewater contaminants in US streams, 1999-2000: a national reconnaissance. Environ Sci Technol. 2002;36: 1202-1211.

[16] Santos LH, Araújo AN, Fachini A, Pena A, Delerue-Matos C, Montenegro MCBSM. Ecotoxicological aspects related to the presence of pharmaceuticals in the aquatic environment. J Hazard Mater. 2010; 175:45-95

[17] Ternes TA, Meisenheimer M, McDowell D, et al. Removal of pharmaceuticals during drinking water treatment. Environ Sci Technol. 2002;36:3855-3863.

[18] Siemens J, Huschek G, Siebe C, Kaupenjohann M. Concentrations and mobility of human pharmaceuticals in the world's largest wastewater irrigation system, Mexico City-Mezquital Valley. Water Res. 2008;42:2124-2134.

[19] Gibson R, Durán-Álvarez JC, León-Estrada K, Chávez A, JiménezCisneros B. Accumulation and leaching potential of some pharmaceuticals and potential endocrine disruptors in soils irrigated with wastewater in the Tula Valley, Mexico. Chemosphere. 2010;81: 1437-1445.

[20] Félix-Cañedo TE, Durán-Álvarez JC, Jiménez-Cisneros B. The occurrence and distribution of a group of organic micropollutants in Mexico City's water sources. Sci Total Environ. 2013;454/455:109-118.

[21] Brun L, Bernier M, Losier R, Doe K, Jackman P, Lee H. Pharmaceutically active compounds in Atlantic Canadian sewage treatment plant 
effluents and receiving waters and potential for environmental effects as measured by acute and chronic aquatic toxicity. Environ Toxicol Chem. 2006;25:2163-2176.

[22] Marques CR, Abrantes N, Gonçalves F. Life-history traits of standard and autochthonous cladocerans: I. Acute and chronic effects of acetylsalicylic acid. Environ Toxicol. 2004;19:518-526.

[23] Marques CR, Abrantes N, Gonçalves F. Life-history traits of standard and autochthonous cladocerans: II. Acute and chronic effects of acetylsalicylic acid metabolites. Environ Toxicol. 2004;19:527-540.

[24] Hoeger B, Dietrich D, Schmid D, Hartmann A. Distribution of intraperitoneally injected diclofenac in brown trout (Salmo trutta $f$. fario). Ecotox Environ Safe. 2008;71:412-418.

[25] Pomati F, Castiglioni S, Zuccato E, Fanelli R, Vigetti D, Calamari D. Effects of a complex mixture of therapeutic drugs at environmental levels on human embryonic cells. Environ Sci Technol. 2006;40: 2442-2447.

[26] Gómez-Oliván LM, Neri-Cruz N, Galar-Martínez M, et al. Assessing the oxidative stress induced by paracetamol spiked in artificial sediment on Hyalella azteca. Water Air Soil Pollut. 2012;223:5097-5104.

[27] Gómez-Oliván LM, Galar-Martínez M, García-Medina S, Valdés-Alanís $\mathrm{A}$, Islas-Flores $\mathrm{H}$, Neri-Cruz N. Genotoxic response and oxidative stress induced by diclofenac, ibuprofen and naproxen in Daphnia magna. Drug Chem Toxicol. 2014;37:391-399.

[28] Islas-Flores H, Gómez-Oliván LM, Galar-Martínez M, Colín-Cruz A, Neri-Cruz N, García-Medina S. Diclofenac-induced oxidative stress in brain, liver, gill and blood of common carp (Cyprinus carpio). Ecotoxicol Environ Safe. 2013;92:32-38.

[29] Islas-Flores H, Gómez-Oliván LM, Galar-Martínez M, García-Medina S, Neri-Cruz N, Dublán-García O. Effect of ibuprofen exposure on blood, gill, liver, and brain on common carp (Cyprinus carpio) using oxidative stress biomarkers. Environ Sci Pollut Res. 2014; DOI 10.1007/s11356-013-2477-0.

[30] Oviedo-Gómez DGC, Galar-Martínez M, García-Medina S, RazoEstrada C, Gómez-Oliván LM. Diclofenac-enriched artificial sediment induces oxidative stress in Hyalella azteca. Environ Toxicol Pharmacol. 2010;29:39-43.

[31] Kovacic P, Jacintho JD. Reproductive toxins: pervasive theme of oxidative stress and electron transfer. Curr Med Chem. 2001;8:863892.

[32] Dennery PA. Effects of oxidative stress on embryonic development. Birth Defects Res C Embryo Today. 2007;81:155-162.

[33] Lander HM. An essential role for free radicals and derived species in signal transduction. Faseb J. 1997;11:118-124.

[34] Sahambi SK, Hales BF. Exposure to 5-bromo-2'-deoxyuridine induces oxidative stress and activator protein-1 DNA binding activity in the embryo. Birth Defects Res Part a-Clin Mol Teratol. 2006;76:580-591.

[35] Van der Oost RB, Vermeulen JNPE. Fish bioaccumulation and biomarkers in environmental risk assessment: a review. Environ Toxicol Pharmacol. 2003;13:57-149.

[36] Huang DJ, Zhang YM, Song G, Long J, Liu JH, Ji WH. Contaminants-induced oxidative damage on the carp Cyprinus carpio collected from the Upper Yellow River, China. Environ Monit Assess. 2007;128:483-488

[37] Cleuvers M. Mixture toxicity of the anti-inflammatory drugs diclofenac, ibuprofen, naproxen and acetylsalicylic acid. Ecotoxicol Environ Safe. 2004;59:309-315.

[38] Cleuvers M. Initial risk assessment for three beta-blockers found in the aquatic environment. Chemosphere. 2005;59:199-205.

[39] Silva E, Rajapakse N, Kortenkamp A. Something from "nothing" eight weak estrogenic chemicals combined at concentrations below
NOECs produce significant mixture effects. Environ Sci Technol. 2002;36:1751-1756.

[40] Yamanaka H, Sogabe A, Handoh IC, Kawabata Z. The effectiveness of clove oil as an anaesthetic on adult common carp, Cyprinus carpio L. J Anim Vet Adv. 2011;10:210-213.

[41] Büege JA, Aust SD. Microsomal lipid peroxidation. Methods Enzymol. 1979;52:302-310.

[42] Misra P, Fridovich I. The role of superoxide anion in the autoxidation of epinephrine and a simple assay for superoxide dismutase. J Biol Chem. 1972;247:3170-3175.

[43] Radi R, Turrens J, Chang Y, Bush M, Capro D, Freeman A. Detection of catalase in rat heart mitochondria. J Biol Chem. 1991;226: 22028-22034.

[44] Gunzler W, Flohe-Clairborne A. Glutathione peroxidase. In: GreenWald RA, ed. Handbook of Methods for Oxygen Radical Research. Boca Raton: CRC Press; 1985:285-290

[45] Stephensen E, Svavarsson J, Sturve J, Ericson G, Adolfsson-Ena M, Forlin L. Biochemical indicators of pollution exposure in shorthorn sculpin (Myoxocephalus scorpius), caught in four harbours on the southwest of Iceland. Aquat Toxicol. 2000;48(4):431-442.

[46] Bradford MM. A rapid and sensitive method for the quantitation of microgram quantities of protein utilizing the principle of protein dye binding. Anal Biochem. 1976;72:248-254.

[47] Cavas T, Ergene-Gözükara S. Induction of micronuclei and nuclear abnormalities in Oreochromis niloticus following exposure to petroleum refinery and chromium processing plant effluents. Aquat Toxicol. 2005; 74:264-271.

[48] li-Yong K, Chang-Kee H. Comparative evaluation of the alkaline comet assay with the micronucleus test for genotoxicity monitoring using aquatic organisms. Ecotoxicol Environ Safe. 2006; 64:288-297.

[49] Bolognesi C, Perrone E, Roggieri P, Pampanin DM, Sciutto A. Assessment of micronuclei induction in peripheral erythrocytes of fish exposed to xenobiotics under controlled conditions. Aquat Toxicol. 2006;78:S93-S98.

[50] Tice R, Anderson D, Burlinson D, et al. The single cell gel/comet assay: guidelines for in vitro and in vivo genetic toxicology testing. Environ Mol Mutagen. 2000;35:206-221.

[51] Lankoff A, Banasik A, Duma A, et al. A comet assay study reveals that aluminium induces DNA damage and inhibits the repair of radiation-induced lesions in human peripheral blood lymphocytes. Toxicol Lett. 2006;161:27-36.

[52] Praskova E, Voslarova E, Siroka Z, et al. Assessment of diclofenac $\mathrm{LC}_{50}$ reference values in juvenile and embryonic stages of zebrafish (Danio rerio). Pol J Vet Sci. 2011;14:545-549.

[53] Stegeman JJ, Livingstone DR. Forms and functions of cytochrome P450. Comp Biochem Physiol C-Pharmacol Toxicol Endocrinol. 1998; 121:1-3.

[54] Blanco G, Martínez C, García-Martín E, Agúndez JA. Cytochrome P450 gene polymorphisms and variability in response to NSAIDs. Clin Res Regul Aff. 2005;22:57-81.

[55] Zanger UM, Turpeinen M, Klein K, Schwab M. Functional pharmacogenetics/genomics of human cytochromes P450 involved in drug biotransformation. Anal Bioanal Chem. 2008;392:10931108.

[56] Tang W. The metabolism of diclofenac - enzymology and toxicology perspectives. Curr Drug Metab. 2003;4:319-329.

[57] Gomez C, Constantine L, Moen M, Vaz A, Huggett DB. Ibuprofen metabolism in the liver and gill of rainbow trout, Oncorhynchus mykiss. Bull Environ Contam Toxicol. 2011;86:247-251. 
[58] Boelsterli UA. Mechanistic Toxicology. The Molecular Basis of How Chemicals Disrupt Biological Targets. 2nd ed. Boca Ratón, FL: CRC Press; 2007.

[59] Deng A, Himmelsbach M, Zhu QZ, et al. Residue analysis of the pharmaceutical diclofenac in different water types using ELISA and GC-MS. Environ Sci Technol. 2003;37:3422-3429.

[60] Bast A. Oxidative stress and calcium homeostasis. In: Halliwell B, Aruoma OI, editors. DNA and Free Radicals. London: Ellis Horwood; 1993:95-108.

[61] Del Rio D, Stewart AJ, Pellegrini N. A review of recent studies on malondialdehyde as toxic molecule and biological marker of oxidative stress. Nutr Metab Cardiovasc Dis. 2005;15:316-328.

[62] Nava-Álvarez R, Razo-Estrada AC, García-Medina S, Gómez-Olivan LM, Galar-Martínez M. Oxidative stress induced by mixture of diclofenac and acetaminophen on common carp (Cyprinus carpio). Water Air Soil Pollut. 2014;225:1873

[63] Doi H, Iwasaki H, Masubuchi Y, Nishigaki R, Horie T. Chemiluminescence associated with the oxidative metabolism of salicylic acid in rat liver microsomes. Chem-Biol Interact. 2002;140: 109-119.

[64] McCord JM, Fridovich I. Superoxide dismutase. An enzymic function for erythrocuprein (hemocuprein). J Biol Chem. 1969;22:60496055.

[65] Filho DW. Fish antioxidant defenses - a comparative approach. Braz J Med Biol Res. 1996;29:1735-1742.

[66] Hai DQ, Varga I, Matkovics B. Organophosphate effects on antioxidant system of carp (Cyprinius carpio) and catfish (Ictalurus nebulosus). Comp Biochem Physiol C Pharmacol Toxicol Endocrinol. 1997; 117:83-88.

[67] Ahmad I, Hamid T, Fatima M, et al. Induction of hepatic antioxidants in freshwater catfish (Channa punctatus Bloch) is a biomarker of paper mill effluent exposure. Biochim Byophis Acta. 2000;1523:37-48.

[68] Rajamanickam V, Muthuswamy N. Biochemical changes of antioxidant enzymes in common carp (Cyprinus carpio L.) after heavy metal exposure. Turk J Vet Anim Sci. 2009;33:273-278.

[69] Bagnyukova TV, Chahrak OI, Lushchak VI. Coordinated response of goldfish antioxidant defenses to environmental stress. Aquat Toxicol. 2006;78:325-331

[70] Kim I-Y, Hyun C-K. Comparative evaluation of the alkaline comet assay with the micronucleus test for genotoxicity monitoring using aquatic organisms. Ecotox Environ Safe. 2006;64:288-297.

[71] Al-Sabti K, Metcalfe CD. Fish micronuclei for assessing genotoxicity in water. Mutat Res Genet Toxicol. 1995;343(2):121-135.

[72] Palhares D, Grisolia CK. Comparison between the micronucleus frequencies of kidney and gill erythrocytes in tilapia fish, following mitomycin C treatment. Genet Mol Biol. 2002;25:281-284.
[73] Torres deLemos C, Milan Rödel P, Regina Terra N, D'avila de Oliveira NC, Erdtmann B. River water genotoxicity evaluation using micronucleus assay in fish erythrocytes. Ecotoxicol Environ Safe. 2007;66:391-401.

[74] Canistro D, Melega S, Ranieri D, et al. Modulation of cytochrome P450 and induction of DNA damage in Cyprinus carpio exposed in situ to surface water treated with chlorine or alternative disinfectants in different seasons. Mutat Res-Fundam Mol Mech Mutagen. 2012;729:1): 81-9. (

[75] Lo YYC, Wong JMS, Cruz TF. Reactive oxygen species mediated cytokine activation of c-Jun NH2-terminal kinases. J Biol Chem. 1996;271:15703-15707.

[76] Shi X, Jiang H, Mao Y, Ye J, Saffiotti U. Vanadium (IV)-mediated free radical generation and related 2'-deoxyguanosine hydroxylation and DNA damage. Oncology. 1996;106:27-38.

[77] Reid TM, Fry M, Loeb LA. Endogenous mutations and cancer. Princess Takamatsu Symp. 1991;22:224-229.

[78] Gulbins E, Dreschers S, Bock J. Role of mitochondria in apoptosis. Exp Physiol. 2003;88:85-90.

[79] Chan TA, Morin PJ, Vogelstein B, Kinzler K. Mechanisms underlying nonsteroidal antiinflammatory drug-mediated apoptosis. Proc Natl Acad Sci. 1998;95(2):681-686.

[80] Cao Y, Pearman AT, Zimmerman GA, Mclntyre TM, Prescott SM. Intracellular unesterified arachidonic acid signals apoptosis. Proc Natl Acad Sci. 2000;97(21):11280-11285.

[81] Scorrano L, Penzo D, Petronilli V, Pagano F, Bernardi P. Arachidonic acid causes cell death through the mitochondrial permeability transition: implications for tumor necrosis factor- $\alpha$ apoptotic signaling. J Biol Chem. 2001;276(15):12035-12040.

[82] Hannun YA. Functions of ceramide in coordinating cellular responses to stress. Science. 1996;274(5294):1855-1859.

[83] Olanow CW, Arendash GW. Metals and free radicals in neurodegeneration. Curr Opin Neurol. 1994;7:548-558.

[84] Dalle-Donne I, Scaloni A, Giustarini D, Cavarra E, Tell G, Lungarella G. Proteins as biomarkers of oxidative/nitrosative stress in diseases: the contribution of redox proteomics. Mass Spectrom Rev. 2005;24: 55-99.

How to cite this article: Islas-Flores H, Manuel Gómez-Oliván L, Galar-Martínez M, et al. Cyto-genotoxicity and oxidative stress in common carp (Cyprinus carpio) exposed to a mixture of ibuprofen and diclofenac. Environmental Toxicology. 2017;00:1-14. doi:10.1002/tox.22392. 